\title{
EARNSCLEUGH STATION - PAST, PRESENT AND FUTURE
}

A. CAMPBELL

Earnscleugh Station, Clyde

Earnscleugh Station covers 24,948 ha, extending from Cromwell Gorge to Fruitlands and over Old Man Range into the Fraser Basin. Altitude varies from $150 \mathrm{~m}$ at the homestead to $1600 \mathrm{~m}$ at the translator on top of Old Man Range. Climate has hot dry summers, cold winters. Rainfall $300 \mathrm{~mm}$ at homestead rising to $1500 \mathrm{~mm}$ on back boundary.

Land Utillsation

9,200 ha Summer grazing. Predominantly blue tussock and snowgrass.

7,400 ha Improvable country of which 700 ha is being maintained with superphosphate.

7,900 ha Dry country - most under $600 \mathrm{~m}$.

250 ha Wild flood irrigation on non-arable country.

$64 \mathrm{ha}$ Cultivated - in grass and lucerne with 50 ha border dyke irrigated.

16 ha Orchard development.

Table 1: Stock carried.

20,300 stock units wintered 1985 . reduced to 19,000 in 1986

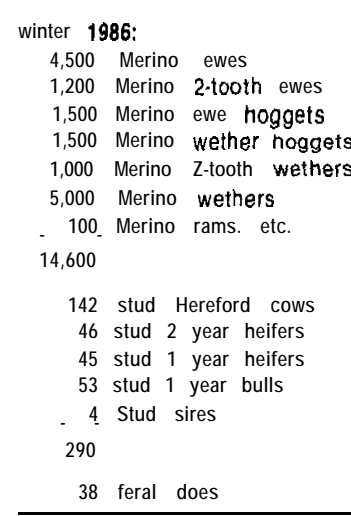

38 feral does

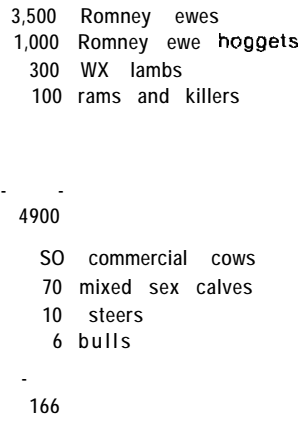

\section{PAST}

Earnscleugh was purchased in 1981 carrying 15,236 stock units. $80 \mathrm{~km}$ of new fencing was erected increasing the number of blocks from 24 to 67 . Sheepshead (area 2,800 ha) $-1,300$ ha was fenced into 40 to 80 ha blocks, with 950 ha, including 250 ha of flood irrigated land, topdressed with $250 \mathrm{~kg}$ per ha of sulphur super. Merino's were changed to Romneys on Sheepshead due to footrot problems. Stock numbers were increased to 20,300 stock units. Stud horned Hereford herd was built up from 50 cows brought from my previous property, to 140 cows and supporting stock.

\section{PRESENT}

Development, except horticulture, has ceased and expenditure is being reduced as we move into survival mode. No super will be applied this season apart from a trial to evaluate the use of sulphur. Stock numbers have been decreased partly due to rabbits and partly with an emphasis on increasing per head performance. 
Table 2: Development Costs

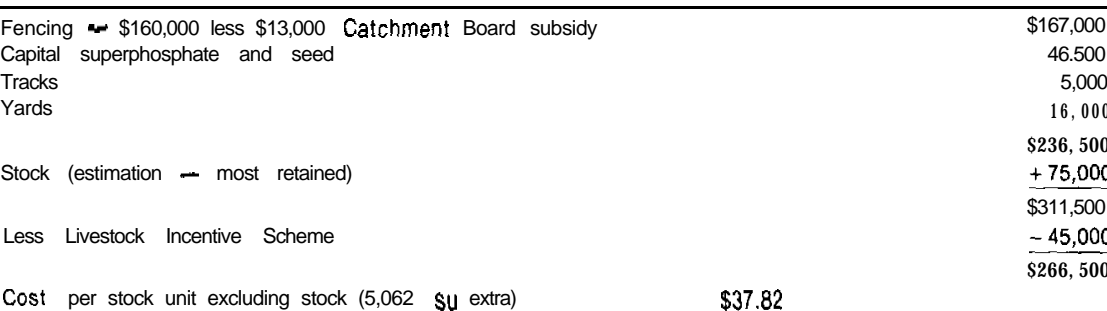

Cost per stock unit excluding stock (5,062 \$u extra) $\$ \$ 7.82$

Return:

Topdressing maintenance per su extra $\$ 5.45$

Extra expenditure $\quad 5.00$

Interest on $\$ 266,500$ at $23 \%$

Gross return per su $1985166 \quad \$ 22.53$

Income: $\quad \$ 7.26$ per su extra

Return on capital: $\quad 37 \%$

NOTE: Based on interest rate of $14 \%$ at start of development income per stock unit would have been $\$ 14.63$.

\section{Objective Measurement}

This is being used by mid-side sampling the hoggets and weighing the fleeces, thus allowing culling decisions to be made on accurate micron counts and clean fleece weights.

Testing is not cheap at $\$ 2.50$ per head $(\$ 6,000$ last year) but more accurate classing and improved prices for surplus stock probably covered this. Where we struggled to get a line of 4 bales under 17.5 micron in the past, last season we managed 26 bales.

Ewe hoggets under 17 microns are being identified and are mated to the finest Merryville blood rams I can find, with the objective being to maintain 500 super-fine ewes capable of supplying wethers suitable for Sharlea wool production.

\section{Stud Herd}

We are in the process of increasing the cow herd to 300 cows, of which the top producing 100 will form the bull breeding nucleus.

Heifers are screened using performance records and only the top producers, based on their first calf, make it into the nucleus.

Ova transplant has been used on top cows and we have made widespread use of artificial insemination.

Bulls were given the Blockey Serving Capacity Test this season, and while not having much faith in it at the time, I now consider it very important. Four bulls that failed the test were re-tested 3 months later and failed again for the same reasons.

Those 4 bulls, if sold, would have at the worst left no calves or at the best very few cows would have been settled in the first cycle.

\section{WX Lambs}

This season we kept the top 300 crypt romney lambs for the WX grade, and though there has been a lot of mucking around with them, the price received makes it well worthwhile. Those sold to date have cleared $\$ 31.50$ plus $\$ 2.50$ of wool clear after shearing costs.

Goats

Forty feral does were purchased last spring and I am more than happy with their briar control. They have been easy to handle apart from in the woolshed or yards. They have been mated to angora bucks. 


\section{Horticulture}

Earnscleugh has a considerable area of country suitable for horticulture, and at this stage, development has started on a 16 ha orchard block. This area had shelter planted last season and the first block of 5 ha has been planted out during the winter with trees grown in our own nursery. Export varieties of nectarines, peaches, apricots and Asian pears have been planted.

On budgeted returns the orchard has the ability to earn more than the entire property is doing at present.

Cost of development is very high, with $\$ 200,000$ for frost protection and irrigation done, and appreciable returns 3 to 4 years away.

\section{Sugar Maples}

A few sugar maple trees have been grown in amenity plantings to see how they grow. This is a long term venture as it takes from 10 to 15 years before the trees can be tapped.

\section{FUTURE}

There is potential for increasing the stock carrying capacity to 30,000 stock units with oversowing and topdressing. Most of the fencing has been erected and a large part of the 7,400 ha which is improvable has been seeded in 1973 and does not require reseeding.

\begin{tabular}{lr} 
Table 3: Costing & \\
\hline Super and sowing & $\$ 294,000$ \\
Seed & 22,500 \\
Fencing & 27,500 \\
Airstrips & 25,000 \\
& 379,400 \\
Stock & 200,000 \\
& $\$ 579,400$ \\
Debt servicing at 20\% & $\$ 11.59 / \mathrm{su}$ \\
Super maintenance & 6.72 \\
Extra expenditure & 5.00 \\
& $\$ 23.31$ \\
Gross return per su & 29.79 \\
Income: & $56.48=31 \%$ return on capital
\end{tabular}

While the figures look alright, the present uncertainty makes continued development very hazardous. The future price of superphosphate, interest rates, fluctuations in the dollar and reduced equity in the property are all changing daily and what would once have been a reasonable proposition probably needs a bigger safety margin.

Goats

Will be slowly expanded. While I consider them to be a viable diversification, their returns aren't much higher than Merino sheep and the capital cost is much higher. I can see a time in the future when Earnscleugh will run 1,000 goats.

\section{Horticulture}

If the first development proves to be a success, then there will be continued expansion of the area in orchard. There are 200 ha of suitable land with water rights and double that area without.

Sharlea

At this stage the object is to produce sheep for selling to Sharlea farmers but if sheds aren't established we will look to convert an existing shed to house 300 sheep. 
The expected return at $3 \mathrm{~kg}$ per head selling at $\$ 30$ per kilo (last season $\$ 40$ ), replacement sheep worth $\$ 50$, and grain at $\$ 200$ per tonne, would leave a margin of $\$ 9,500$.

Tourism

Earnscleugh has a considerable amount to offer the tourist, e.g. cross-country skiing, gold mining, fishing, tramping, horse riding, four wheel drive tours, shooting of game birds, rabbits and with a fenced block deer, as well as seeing a working sheep station.

Being close to Alexandra, staff for such an enterprise would be readily available. Queenstown is only 20 minutes away by helicopter or plane.

The limitations, at present, are lack of high class accommodation in Alexandra and lack of knowledge on the management required to promote such a venture. This could be overcome by attracting an existing tourist company to invest in such an enterprise and build accommodation on the property.

Other considerations include the group marketing of mid-side sampled, micron tested superfine wool.

Supplying the restaurant trade with Merino mutton, long regarded as the best, naturally grown and lean, and able to be promoted with its high country image.

\section{SUMMARY}

Survival over the next few years is the main concern. Like all properties purchased in recent years, we are under considerable pressure with falling land prices and high interest rates. Rabbits remain a problem with between 2,000 to 4,000 ha out of production at any time. With Rhodamine bait trials being used to assess bait acceptance we have no prior warning of when a block may be poisoned, thus towards the end of winter we regularly have the situation of country to be grazed out not being able to be used and sheep having to be left short of feed. Under the user pays policy of government, we could well by paying over $\$ 10$ per stock unit for pest destruction by 1991. This is totally unaffordable and with our present means of killing rabbits proving ineffective, it is imperative that myxomatosis is introduced quickly.

We are coming under increasing pressure from the environmental lobby to retire the Fraser Basin. This area is one of the best summer grazing blocks in the high country with a dense sward of blue tussock over all but the highest $200 \mathrm{~m}$. Its use is vital to the balance of Earnscleugh and would reduce the present carrying capacity by 6,000 to 8,000 stock units. By not being able to spell the dry front country, the rabbit problem would be increased and the country under $630 \mathrm{~m}$ would be totally denuded of cover.

In conclusion, what has been done to date is done and a lot of what is projected for the future may never get off the drawing board. On hindsight, I have no regrets of decisions made in 1981 and if the situation was the same again, I would follow the same pattern. Finally, I am sure there is room on Earnscleugh for recreationalists, nature lovers, and some of the greatest fine wool growing in the world. 